\title{
PENGARUH VARIETAS PADI (Oryza sativa L.) DAN JENIS KELAMIN KEONG EMAS (Pomacea sp.) TERHADAP DAYA RUSAK KEONG EMAS PADA TANAMAN PADI
}

\author{
Rani Wijayanti, Lestari Wibowo \& Solikhin \\ Jurusan Agroteknologi, Fakultas Pertanian, Universitas Lampung \\ J1. Prof. Dr. Soemantri Brojonegoro No. 1 Bandar Lampung 35145 \\ Email:Raniwijayanti32@gmail.com
}

\begin{abstract}
ABSTRAK
Padi (Oryza sativa L.) merupakan tanaman pangan sumber utama untuk memenuhi kebutuhan nutrisi dalam tubuh. Terdapat beberapa kendala yang mengganggu pada budidaya tanaman padi, salah satu diantaranya adalah keong emas. Tujuan penelitian ini untuk mempelajari pengaruh varietas padi terhadap daya rusak keong emas pada tanaman padi, mempelajari pengaruh jenis kelamin keong emas terhadap daya rusaknya pada tanaman padi, dan mempelajari pengaruh interaksi varietas dan jenis kelamin keong emas terhadap daya rusaknya pada tanaman padi. Penelitian ini dilakukan di Laboratorium Proteksi Tanaman Gadingrejo, Kabupaten Pringsewu. Bahan yang digunakan adalah keong emas jantan, keong emas betina, varietas Ciherang, dan varietas lokal (padi ketan putih). Percobaan menggunakan rancangan acak kelompok faktorial ( 2 x 4). Faktor pertama adalah varietas padi terdiri atas varietas Ciherang dan lokal. Faktor kedua adalah jenis kelamin keong emas terdiri atas tanpa keong emas, dua ekor keong emas jantan, dua ekor keong emas betina, dan keong emas jantan dan betina yang diulang sebanyak 3 kali. Data penelitian dianalisis dengan sidik ragam dan dilanjutkan dengan uji Beda Nyata Terkecil (BNT) pada taraf 5\%. Hasil penelitian menunjukkan bahwa (1) varietas padi tidak berpengaruh terhadap daya rusak keong emas pada tanaman padi, (2) perbedaan jenis kelamin keong emas jantan dan betina tidak menyebabkan perbedaan intensitas kerusakan tanaman padi, dan intensitas kerusakan yang terjadi sebesar 84,17\%, (3) tidak ada interaksi antara varietas padi dan jenis kelamin keong emas terhadap daya rusaknya pada tanaman padi.
\end{abstract}

Kata kunci: daya rusak, keong emas, varietas padi

\section{PENDAHULUAN}

Padi (Oryza sativa L.) merupakan tanaman pangan sumber utama untuk memenuhi kebutuhan nutrisi dalam tubuh. Kandungan nutrisi yang terdapat pada beras diantaranya karbohidrat, vitamin B1, protein, lemak, dan kalori (Patty dkk., 2013). Namun, biasanya dalam budidaya menemukan beberapa kendala yang dapat mengganggu tanaman padi, diantaranya adalah gangguan hama dan penyakit tanaman.

Hama merupakan organisme pengganggu tanaman dan dapat menurunkan nilai kualitas suatu tanaman. Suatu hama dapat berkembang biak dipengaruhi oleh kondisi lingkungan yang mendukung, tidak ada musuh alami, dan makanan tersedia (Sudarsono, 2012). Salah satu hama yang dapat merusak tanaman padi adalah keong emas (Pomacea sp.).

Keberadaan keong emas di lahan budidaya padi mengakibatkan kerusakan. Keong emas dapat merusak tanaman padi dengan memakan bagian pangkal batang tanaman yang baru pindah tanam dan menghancurkan tanaman saat tanaman muda (Widiarta dan Suharto, 2008). Pada serangan keong emas yang parah juga dapat mengakibatkan tanaman padi yang ditanam habis tidak tersisa. Namun belum diketahui pengaruhnya jenis kelamin keong emas terhadap daya rusak pada tanaman padi.

Varietas unggul memiliki keunggulan seperti tahan terhadap hama dan penyakit tertentu, rasa nasi, dan respon terhadap pupuk (Untung, 1996). Penggunaan varietas tahan merupakan cara pengendalian yang paling efektif, murah dan ramah lingkungan. Selain itu, penggunaan varietas tahan merupakan cara pengendalian yang paling umum dan mudah dilakukan oleh petani. Namun demikian, penanaman padi dari varietas unggul belum sepenuhnya efektif, karena pada umumnya varietas tahan hanya memiliki ketahanan terhadap satu jenis OPT (organisme pengganggu tanaman) saja, dan hingga saat ini belum ada dilaporkan varietas yang memiliki deskripsi yang tahan terhadap serangan hama keong emas, selain itu perbedaan antara jenis kelamin jantan dan betina perlu diketahui pengaruhnya terhadap daya rusak pada beberapa 
varietas padi. Oleh karena itu, perlu dilakukan penelitian untuk mengetahui varietas padi yang tahan terhadap keong emas dan pengaruh jenis kelamin keong emas terhadap daya rusak tanaman padi.

\section{BAHAN DAN METODE}

Penelitian ini dilaksanakan di Laboratorium Proteksi Tanaman Pangan dan Hortikultura Gadingrejo, Kabupaten Pringsewu. Penelitian ini berlangsung pada bulan April sampai deengan Juni 2015. Dalam penelitian ini digunakan alat-alat seperti meteran gulung, bambu, lembaran plastik dengan ukuran $1 \times 1 \mathrm{~m}^{2}$, jangka sorong. Bahan-bahan yang dibutuhkan dalam penelitian ini adalah tanaman padi varietas Ciherang dan lokal (padi ketan putih), pupuk Urea, pupuk SP-36, tanah sawah, air, keong emas betina dan jantan berukuran $2,0 \mathrm{~cm}$. Penelitian daya rusak keong emas pada beberapa varietas dilakukan pada petak sawah buatan.

Percobaan menggunakan rancangan acak kelompok faktorial $(2 \times 4)$ dan dikelompokkan berdasarkan naungan di sekitar petak percobaan. Faktor pertama adalah varietas padi terdiri atas varietas Ciherang dan lokal. Faktor kedua adalah kombinasi jenis kelamin keong emas terdiri atas kontrol (tanpa keong emas), dua ekor keong emas jantan, dua ekor keong emas betina, dan keong emas jantan dan betina yang diulang sebanyak 3 kali. Data intensitas kerusakan tanaman oleh keong emas dianalisis dengan sidik ragam dan perbedaan nilai tengah perlakuan diuji dengan uji Beda Nyata Terkecil (BNT) pada taraf $5 \%$.

Pengamatan kerusakan tanaman padi dilakukan sehari setelah keong emas diinvestasikan pada petak percobaan. Pengamatan dilakukan sehari sekali selama 16 hari dengan menghitung intensitas kerusakan keong emas pada batang per rumpun tanaman padi. Penghitungan intensitas kerusakan hamadilakukan dengan menggunakan rumus :

$$
\mathrm{I}=\frac{\mathrm{n}}{\mathrm{N}} \times 100 \%
$$

\section{Keterangan:}

$$
\begin{array}{ll}
\mathrm{I} & =\text { Intensitas kerusakan } \\
\mathrm{n} & =\text { Jumlah batang yang terserang } \\
\mathrm{N} & =\text { Jumlah batang/rumpun dalam satu petak }
\end{array}
$$

\section{HASIL DAN PEMBAHASAN}

Pengamatan daya rusak keong emas jantan dan betina pada varietas padi Ciherang dan lokal (padi ketan putih) dilakukan setiap hari selama 16 hari setelah keong emas diinvestasikan pada petak percobaan. Data yang ditampilkan pada Tabel 1. yaitu nilai F hitung data pada pengamatan ke 1 , ke 6 , ke 11 , dan ke 16 karena data tersebut sudah dianggap mewakili data yang lain.

Pada hari ke 1 hari setelah investasi (hsi) menunjukkan bahwa varietas padi, jenis kelamin keong emas, dan interaksi varietas dengan keong emas tidak berpengaruh nyata. Pada pengamatan selanjutnya hingga 16 hsi menunjukkan bahwa perlakuan keong emas berpengaruh nyata, namun varietas dan interaksi antara keong emas dengan varietas tidak berpengaruh nyata terhadap intensitas kerusakan tanaman padi yang diakibatkan keong emas (Tabel 1).

Hasil uji Beda Nyata Terkecil (BNT) 5\% intensitas kerusakan yang diinvestasikan keong emas jantan, keong emas betina, maupun keong emas campuran jantan dan betina tidak berbeda nyata, namun berbeda nyata dengan kontrol (tanpa keong emas) (Tabel 2).

Hasil penelitian menunjukkan bahwa varietas Ciherang dan lokal (padi ketan putih) tidak mempengaruhi intensitas kerusakan yang diakibatkan oleh keong emas jantan maupun betina, sedangkan perlakuan kombinasi jenis kelamin keong emas berpengaruh terhadap kerusakan tanaman padi.

Secara umum keong emas jantan, keong emas betina, dan keong emas campuran jantan dan betina yang diinvestasikan pada kedua varietas tersebut menyebabkan kerusakan pada tanaman muda varietas Ciherang dan lokal sejak 1 hari setelah investasi (hsi) keong emas. Kerusakan tanaman padi dicirikan dengan adanya batang yang rusak akibat rautan lidah keong emas, terdapat daun yang mengambang, dan batang yang roboh.

Kerusakan yang diakibatkan keong emas jantan, keong emas betina, maupun keong emas campuran jantan dan betina pada 1 hsi masih rendah dibawah 5\%. Sesuai dengan penelitian Wulandari (2007), bahwa pada 1 hari setelah tanam keong emas sudah menyebabkan kerusakan terhadap tanaman padi sebesar 0,67\%. Intensitas kerusakan tanaman padi varietas Ciherang maupun lokal (padi ketan putih) terus meningkat hingga 16 hsi. (Gambar 5).

Intensitas kerusakan tanaman padi yang dipengauhi investasi keong emas berbeda nyata dengan tanaman padi yang tidak diinvestasikan keong emas. Keong emas jantan dan keong emas betina yang diinvestasikan tidak mempengaruhi kerusakan yang diakibatkan dari 1 hsi - 16 hsi (Gambar 6). Didukung dengan penelitian Wulandari (2007), bahwa dari hari ke 1-13 pengamatan mengalami peningkatan kerusakan dari $0,67-94 \%$. Pada pengamatan hari ke 15 setelah investasi pada penelitian ini tidak terjadi peningkatan 
Tabel 1. Nilai F hitung analisis ragam intensitas kerusakan tanaman padi

\begin{tabular}{lcccc}
\hline \multirow{2}{*}{ SK } & \multicolumn{4}{c}{ Nilai F hitung pada Analisis Ragam hari ke- } \\
\cline { 2 - 5 } & $1 \mathrm{hsi}$ & $6 \mathrm{hsi}$ & $11 \mathrm{hsi}$ & $16 \mathrm{hsi}$ \\
\hline Kelompok & $2,14 \mathrm{tn}$ & $0,14 \mathrm{tn}$ & $0,32 \mathrm{tn}$ & $0,02 \mathrm{tn}$ \\
Perlakuan & $1,81 \mathrm{tn}$ & $15,64 *$ & $70,14^{*}$ & $218,78^{*}$ \\
Varietas & $2,08 \mathrm{tn}$ & $0,45 \mathrm{tn}$ & $0,72 \mathrm{tn}$ & $0,02 \mathrm{tn}$ \\
Keong emas & $2,82 \mathrm{tn}$ & $46,48^{*}$ & $209,00^{*}$ & $654,94^{*}$ \\
Varietas X Keong emas & $0,50 \mathrm{tn}$ & $0,19 \mathrm{tn}$ & $0,97 \mathrm{tn}$ & $1,38 \mathrm{tn}$ \\
\hline
\end{tabular}

Keterangan: $*$ = Berbeda nyata pada taraf nyata $5 \%, \mathrm{tn}=$ Tidak berbeda nyata pada taraf nyata $5 \%$

Tabel 2. Pengaruh keong emas terhadap daya rusak keong emas pada tanaman padi.

\begin{tabular}{ccccc}
\hline \multirow{2}{*}{ Perlakuan } & \multicolumn{4}{c}{ Intensitas kerusakan (\%) } \\
\cline { 2 - 5 } & $1 \mathrm{hsi}$ & $6 \mathrm{hsi}$ & $11 \mathrm{hsi}$ & $16 \mathrm{hsi}$ \\
\hline P0 & 0,00 & $0,00 \mathrm{~b}$ & $0,00 \mathrm{~b}$ & $0,00 \mathrm{~b}$ \\
P1 & 2,17 & $28,83 \mathrm{a}$ & $70,00 \mathrm{a}$ & $84,17 \mathrm{a}$ \\
P2 & 2,67 & $25,50 \mathrm{a}$ & $68,00 \mathrm{a}$ & $83,17 \mathrm{a}$ \\
P3 & 1,83 & $27,00 \mathrm{a}$ & $66,67 \mathrm{a}$ & $81,50 \mathrm{a}$ \\
\hline BNT 5\% & - & 2,92 & 7,16 & 6,95 \\
\hline
\end{tabular}

Keterangan: hsi $=$ Hari setelah investasi. Nilai dalam kolom yang diikuti oleh huruf yang berbeda menunjukkan berbeda nyata pada uji $\mathrm{BNT} 5 \%$. $\mathrm{P} 0=$ Tanpa investasi keong emas, $\mathrm{P} 1=$ Investasi dua ekor keong emas jantan, $\mathrm{P} 2$ = Investasi dua ekor keong emas betina, $\mathrm{P} 3=$ Investasi keong emas jantan dan keong emas betina.

intensitas kerusakan hingga 16 hari setelah investasi. Hal tersebut diduga karena tekstur batang yang mulai mengeras, sehinngga keong emas tidak menyerang batang padi pada hari ke 15 setelah investasi. Menurut Budiyono (2006), tanaman padi berumur 15 hari setelah pindah tanam sangat rentan terhadap serangan keong emas.

Faktor yang mempengaruhi tingginya tingkat kerusakan tanaman padi adalah populasi keong emas, ukuran keong emas, dan umur tanaman (Suharto dan Kurniawati, 2009). Pada penelitian ini keong emas diinvestasikan kedalam petakan sawah buatan sebanyak 2 ekor/petak. Menurut Wulandari (2007), populasi 2 ekor/petak telah mengakibatkan kerusakan sebesar $94 \%$ selama 13 hari pengamatan dan semakin banyak jumlah populasi keong emas maka tingkat kerusakan semakin tinggi. Berdasarkan penelitian tersebut sesuai dengan hasil yang didapat pada penelitian ini bahwa keong emas sebanyak 2 ekor/petak telah mengakibatkan kerusakan pada 1 hsi sebesar 0,93-3,24\%.

Umur tanaman padi varietas Ciherang dan lokal (padi ketan putih) yang ditanam pada penelitian ini adalah 15 hari setelah semai, sehingga tidak menyebabkan kerusakan yang berbeda antara kedua varietas tersebut. Menurut Porong (2012), umur bibit yang tepat untuk pindah tanam adalah bibit muda berumur 15 hari setelah semai. Bibit muda memiliki kemampuan beradaptasi yang lebih baik dibandingkan dengan bibit tua sehingga tanaman dapat tumbuh lebih baik. Namun, umur bibit muda yang ditanam dan diinvestasikan keong emas jantan dan betina dengan ukuran yang sama yaitu berdiameter $2 \mathrm{~cm}$ menyebabkan kerusakan yang diakibatkan pada tanaman padi tidak berbeda. Menurut Aji (2011), keong emas berukuran 2,00-2,50 cm perlu diwaspadai karena dapat menimbulkan kerusakan yang besar karena memiliki tubuh yang besar, sehingga memerlukan makanan yang lebih banyak untuk memenuhi kebutuhan hidupnya.

Faktor lain yang mempengaruhi kerusakan adalah adanya genangan air sawah yang sesuai untuk keong emas melakukan mobilitas pada petak percobaan. Menurut Wulandari (2007), ketinggian air 2-3 cm merupakan keadaan yang sesuai untuk keong emas bergerak dan menemukan tanaman padi. Pada petak sawah buatan dalam penelitian ini adalah setinggi $2 \mathrm{~cm}$ dan keadaan ini cukup sesuai bagi keong emas untuk bergerak sehingga keong emas dapat menyerang. Sesuai dengan penelitian Wijaya (2006), bahwa ketinggian air $1,5-2,5 \mathrm{~cm}$ mengalami kerusakan tertinggi yang diakibatkan oleh keong emas.

Tingginya tingkat kerusakan tanaman padi varietas Ciherang dan lokal akibat keong emas jantan maupun betina merupakan suatu hal yang perlu diwaspadai, karena dari penelitian ini varietas tanaman 


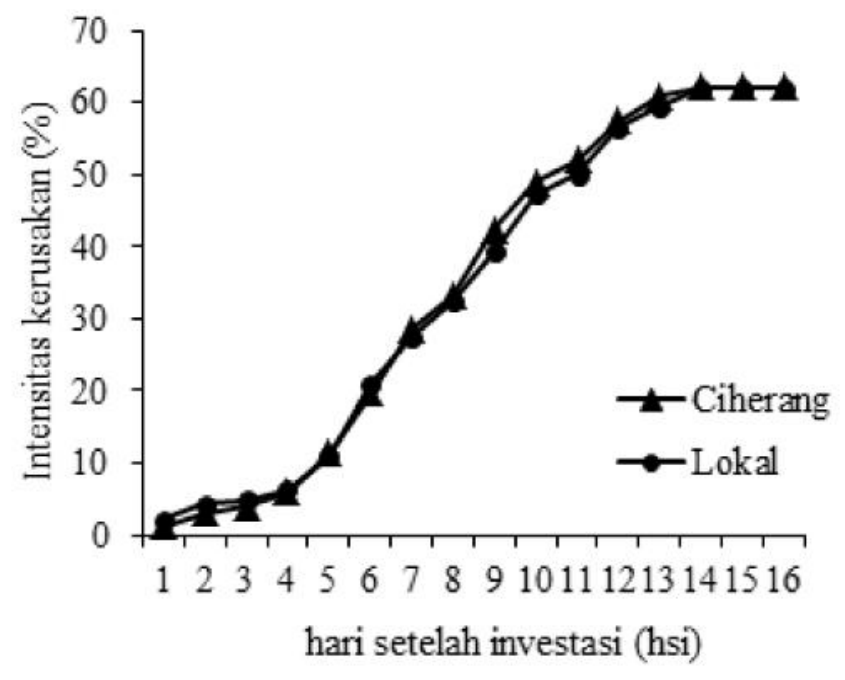

Gambar 1. Grafik intensitas kerusakan tanaman padi pengaruh varietas selama 1-16 hsi.

padi tidak berpengaruh terhadap daya rusak keong emas. Pengamatan yang dilakukan pada penelitian ini setiap sehari sekali pada pagi hari karena keong emas merusak tanaman padi pada malam hari, sedangkan pada siang hari keong emas tidak beraktivitas dan bersembunyi di pinggir. Menurut Suharto dan Kurniawati (2009), keong emas merupakan hewan nokturnal yang sangat rakus dan lebih menyukai tanaman yang lebih lunak untuk dikonsumsi. Keong emas ini menyerang tanaman padi pada malam hari dengan cara meraut pangkal batang dengan lidah kasarnya dan menyebabkan adanya batang yang terpotong ditandai dengan adanya daun yang mengambang di permukaan air.

Serangan keong emas yang terjadi pada penelitian ini menyebabkan rumpun padi tidak dapat tumbuh tunas baru lagi karena keong emas menyerang tanaman padi dimulai dari batang yang berbatasan dengan air dan merobohkan batang, kemudian memakan seluruh bagian tanaman yang mengambang hingga rumpun padi menjadi kosong dan mati. Keong emas jantan dan keong emas betina yang diinvestasikan pada varietas Ciherang dan lokal (padi ketan putih) dengan populasi sebanyak 2 ekor $/ \mathrm{m}^{2}$ pada pengamatan $16 \mathrm{hsi}$ sudah mengakibatkan kerusakan mencapai $84,17 \%$. Sesuai dengan penelitian Aji (2011), bahwa tanaman padi berumur 10 hari sangat rentan terhadap serangan keong emas karena tanaman padi masih lunak. Pada hari selanjutnya kerusakan berkurang disebabkan batang tanaman padi mulai mengeras, sehingga keong emas tidak mudah menyerang.

Apabila serangan keong emas terjadi di lahan sawah maka perlu dilakukan penyulaman. Oleh karena itu, dari hasil penelitian ini diharapkan perlu mewasdai

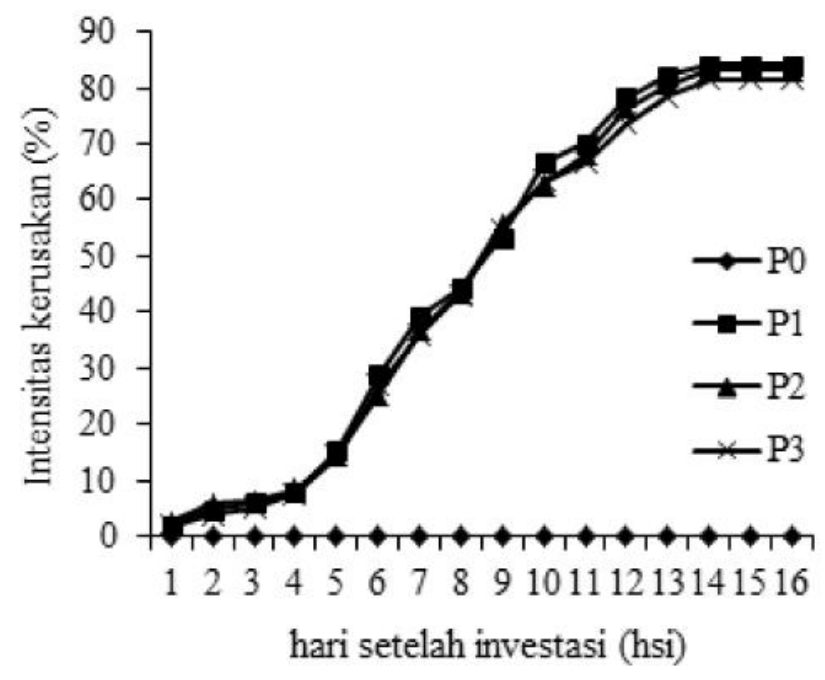

Gambar 2. Grafik intensitas kerusakan tanaman padi pengaruh keong emas selama 1-16 hsi.

budidaya padi pada fase vegetatif terhadap adanya keong emas di lahan budidaya padi di sawah, sehingga pengendalian dapat dilakukan secara tepat.

\section{KESIMPULAN}

Berdasarkan hasil penelitian daya rusak keong emas pada tanaman padi berumur 2 minggu setelah tanam dapat disimpulkan bahwa varietas padi tidak berpengaruh terhadap daya rusak keong emas pada tanaman padi. Perbedaan jenis kelamin keong emas jantan dan betina tidak menyebabkan perbedaan intensitas kerusakan tanaman padi. Intensitas kerusakan yang terjadi sebesar $84,17 \%$. Tidak ada interaksi antara varietas padi dan jenis kelamin keong emas terhadap daya rusaknya pada tanaman padi.

\section{DAFTAR PUSTAKA}

Aji, R. T. P. 2011. Daya rusak berbagai ukuran keong emas (Pomacea sp.) pada berbagai tingkat umur tanaman padi (Oryza sativa L.) fase vegetatif yang ditanam secara tabela. Skripsi. Universitas Lampung. Bandar Lampung.

Budiyono, S. 2006. Teknik mengendalikan keong emas pada tanaman padi. Jurnal Ilmu-ilmu Pertanian. 2(2): 129-132.

Patty, P. S., Kaya, E., dan Silahooy, C. 2013. Analisis status nitrogen tanah dalam kaitannya dengan serapan $N$ oleh tanaman padi sawah di Desa Waimital, Kecamatan Kairatu, Kabupaten 
Seram Bagian Barat. Jurnal Agrologia. 2(1): 51-58.

Porong, V. J. 2012. Perbedaan umur bibit terhadap pertumbuhan dan produksi padi sawah (Oryza sativa L.). Jurnal Eugenia. 18(1): 35-38.

Sudarsono, H. 2013. Ilmu Hama Tumbuhan. Universitas Lampung. Bandar Lampung. $161 \mathrm{hlm}$.

Suharto, H. dan N. Kurniawati. 2009. Keong Emas Dari Hewan Peliharaan Menjadi Hama Utama Padi Sawah. Balai Besar Penelitian Tanaman Padi. Jawa Barat, hlm: 389-391.

Untung, K. 1996. Pengantar Pengelolaan Hama Terpadu. Gadjah Mada University Press. Yogyakarta, hlm: 67- 81.
Widiarta, I. N. dan H. Suharto. 2008. Pengendalian Hama Dan Penyakit Tanaman Padi Secara Terpadu. Balai Besar Penelitian Tanaman Padi. Jawa Barat, hlm: 441- 469.

Wijaya, M. A. S. 2006. Pengaruh ketinggian air sawah terhadap serangan keong emas pada tanaman padi fase vegetatif awal. Skripsi. Universitas Lampung. Bandar Lampung.

Wulandari, A. M. 2007. Pengeruh kepadatan populasi keong emas (Pomacea sp.) terhadap daya rusak keong emas pada tanaman padi (Oryza sativa L.). Skripsi. Universitas Lampung. Bandar Lampung. 